\title{
NUEVAS VISIONES Y APORTACIONES EN LA PINTURA "LA BATALLA DE CLAVIJO", DE LA IGLESIA DE SANTIAGO EL VIEJO DE SEVILLA
}

\author{
NEW VISIONS AND CONTRIBUTIONS OVER \\ “THE BATTLE OF CLAVIJO” IN OLD SANTIAGO'S \\ CHURCH OF SEVILLE
}

\author{
Ignacio Algarín González \\ Investigador de la Universidad de Sevilla \\ ialgaring@gmail.com
}

\begin{abstract}
Estudio de la obra Santiago en la batalla de Clavijo en el que, a través de una revisión de sus fuentes historiográficas, literarias e iconográficas, y en consonancia con los detalles de su restauración, se aporta una nueva lectura iconográfica y una hipótesis sobre su estado original, partiendo de la existencia del olvidado pie.

Palabras clave: Santiago en la batalla de Clavijo, iconografía de Santiago, Mateo Pérez de Alesio, Argote de Molina, Siglo XVI.
\end{abstract}

Study of the work, Santiago in the battle of Clavijo in which, through a review of its historiography, literary and iconographic sources, and consistent with the details of its restoration, a new iconographic reading and a hypothesis about its original status is provided, from the existence of the forgotten foot.

Keywords: Santiago in the Battle of Clavijo, iconography of Santiago, Mateo Pérez de Alesio, Argote de Molina, XVI Century.

Este cuadro (figura 1) fue encargado por Argote de Molina al pintor Mateo Pérez de Alesio en el 1584 mediante un contrato por el que se obligaba a pintar durante un quinquenio. Esto lo convertía en su pintor de cámara, obligándole así a residir en su domicilio y 'hacer y pintar todas las cosas que me fueren mandadas, así en Sevilla como en las islas de Lanzarote y Fuerteventura', cobrando por ello 600 ducados anuales. Debía decorar, así mismo, el museo y la biblioteca, además de pintar el cuadro de Santiago en la batalla de Clavijo para la capilla 
funeraria de Argote, en la iglesia de Santiago ${ }^{1}$. Destaca López Martínez la singularidad del convenio y la importancia del mismo en la escritura otorgada en Sevilla el 19 de octubre de 1584. En este le deja además a cargo un menor que posiblemente sea Felipe de Alesio, hijo desconocido hasta la fecha del pintor y del cual hemos hallado su carta de embarque en el Archivo de Indias en $1598^{2}$.

Argote de Molina fue uno de los primeros coleccionistas ${ }^{3}$ y mecenas. Su colección era un museo manierista del tipo wunderkammer o sala de maravillas, siendo una de las más célebres de la segunda mitad del siglo XVI, sobre la cual Pacheco escribe $^{4}$. Constaba de una biblioteca, armas antiguas, una galería de hombres ilustres relacionados con la tradición de la antigüedad clásica, que él mismo había encargado a Sánchez Cohello; así como fragmentos de la antigüedad y curiosidades, animales exóticos y rarezas, con intención científica como describe el propio Monardes ${ }^{5}$. Llegó a tener tal fama que Felipe II la visitó de incógnito, como escribe Pacheco: “...obligaron a Su Magestad, hallándose en Sevilla, año 1570, a

${ }^{1}$ Contrato dado a conocer por Celestino López Martínez en la sesión de la Academia Sevillana de Buenas letras de 22 de enero de 1937 en PALMA CHAGUACEDA, Antonio: El historiador Gonzalo Argote De Molina. Las Palmas, Ayuntamiento de Las Palmas, 1973, p. 11. n. 15; publicado completo en LÓPEZ MARTÍNEZ, Celestino: "Gonzalo Argote de Molina Historiador y bibliófilo", Archivo Hispalense, Sevilla, 1953, pp. 196-199.

2 A.G.I., CONTRATACION, 5257, n. 2, r. 7v. Libros de Asientos de pasajeros a Indias, el día 31 de Agosto de1598, la carta de Felipe de Alecio, soltero, hijo de Mateo Pérez de Alecio y María de la O, que embarca a Perú como criado del doctor Juan Bautista Ortiz. La primera noticia conocida de la paternidad de Alesio en tierras españolas, permiso que pide el año en el que celebra su padre Mateo, la boda en Lima, a los 51 años con doña María Fuentes de la Cadena.

${ }^{3}$ GESTOSO Y PÉREZ, José: “Curiosidades Antiguas Sevillanas. Serie Segunda”, El Correo de Andalucía, 1910, p. 237.

4 "Después destos exercicios de las armas, se dio al estudio de las letras, i hizo en sus casas de cal de Francos (con buena elección a mucha costa suya) un famoso museo, juntando raros i peregrinos libros de istorias impresas y de mano, luzidos i extraordinarios cavallos, de linda raça $i$ vario pelo, i una gran copia de armas antiguas i modernas, que entre diferentes cabeças de animales y famosas pinturas de fábulas i retratos de insignes hombres, de mano de Alonso Sánchez Coello, hazían maravillosa correspondencia.”, PACHECO, Francisco: Libro De Descripción De Verdaderos Retratos De Ilustres y Memorables Varones. Sevilla, 15991644, Diputación de Sevilla. Edición en foto-cromo-typia, 1985, pp. 273-274; GESTOSO Y PÉREZ, José, Curiosidades Antiguas ..., op. cit., p. 267.

5 “...este animal saqué de otro natural, que está en el museo de Gonzalo de Molina, un caballero desta ciudad, en el qual ay mucha cantidad de libros de varia lectión, y muchos generos de animales y aves, y otras cosas curiosas, traydas así de la India Oriental, como Occidental, y otras partes del mundo, y gran copia de monedas y piedras antiguas, y diferencias de armas, que con gran curiosidad y con generoso ánimo ha allegado.”, MONARDES, Nicolás: Historia medicinal de las cosas que se traen de nuestras Indias occidentales que sirven en medicina, Sevilla, 1988, reimpresión de la edición de 1574. Fol. 81. 
venir en un coche disfraçado, por orden de don Diego de Córdova, a onrar tan celebrado camarín" ". José Ramón López Rodríguez en su Historiografía hace un guiño a la edad de Argote, que por aquel entonces contaba con veintidós años, y a la seriedad de Felipe II $^{8}$. Argote logró un lugar destacado entre los investigadores de archivos de la segunda mitad del siglo XVI, incluso obtuvo una orden de Felipe II del año 1576 instando a oidores, presidentes y corregidores de Andalucía a que le permitiesen ver los archivos del reino9. También recogía coplas y cantares populares, entre los que se cuenta la versión en castellano de cierto cantar lastimero según oyó a los moriscos de Granada ${ }^{10}$.

El lienzo se pintó para la iglesia de Santiago, situada hoy en la calle homónima del barrio de Santa Catalina. No está claro la fecha de su fábrica, pero se considera de origen visigótica y luego transformada en mezquita e incluso sinagoga, mientras otros creen que fue levantada por el propio san Fernando tras la conquista ${ }^{11}$.

El retablo mayor fue encargado por Argote de Molina al maestro escultor Andrés de Ocampo el 20 de Febrero de $1589^{12}$. La obra se paralizó por falta de liquidez y posteriormente por la muerte de Argote, siendo terminada diez años más tarde por la hermana del difunto, doña Francisca de Mexía. Esta le encarga a Ocampo que siguiera una nueva traza del arquitecto Vermondo Resta, fechada en $1599^{13}$.

${ }^{6}$ PACHECO, Francisco: Libro de descripción..., op. cit., p. 274; GESTOSO Y PÉREZ, José: Curiosidades Antiguas Sevillanas, op. cit., p. 268.

${ }^{7}$ LÓPEZ RODRÍGUEZ, José Ramón: "Sevilla, el nacimiento de los museos, América y la Botánica”, en GASCÓ, Fernando y BELTRÁN, José: La Antigüedad como argumento II. Historiografía de arqueología e historia antigua en Andalucía, Sevilla, 1995, pp. 75-97, v. n. 67.

${ }^{8}$ No así en su juventud. El embajador Federico Badoaro, en su informe a la Signoria veneciana en 1557 dice de él: «Hace uso inmoderado de ciertos platos, y, sobre todo, de pasteles. Se siente atraído por las mujeres. Una de las diversiones es ir disfrazado, de noche, incluso en medio de los asuntos más graves, y se divierte con toda clase de juegos», apud. LÓPEZ RODRÍGUEZ, José Ramón: Sevilla, el nacimiento.., op. cit., pp. 75-97.

${ }^{9}$ LÓPEZ MARTÍNEZ, Celestino: Capitulos para la biografía del historiador Argote de Molina, Sevilla, Asociación Española para el Progreso de las Ciencias, 1917, p. 191.

${ }^{10}$ Ibídem, p. 202.

${ }^{11}$ La sitúa en época de los godos "Diéronle esta advocación en memoria del invencible Santiago, el cual paró en una de las casas sobre cuyo terreno fabricaron la iglesia." y se cree que fue mozárabe; GÓMEZ AZEVES, Antonio: Antigüedades, bellezas y sepulcros de la Iglesia de Santiago el Mayor, vulgo, el viejo, Sevilla, Imprenta del Porvenir, 1865, p. 5.

${ }_{12}$ El 20 de febrero de 1589 Argote apodera a Ocampo para cobrar del librero cordobés Gabriel Ramos 100 ducados en cuenta para la hechura y aderezo del retablo. PALOMERO PÁRAMO, Jesús M.: El retablo sevillano del Renacimiento : análisis y evolución : (1560-1629), Sevilla, Diputación Provincial de Sevilla, 1983, p. 307.

${ }^{13}$ Ibídem, p. 308. 
La novedosa tipología de este retablo, llamada de 'gran lienzo de Altar', que llega a finales del XVI desde Italia, se configuraba mediante un lienzo o lienzos más pequeños en los bancos y otras partes del retablo. Este esquema fue introducido por Alesio ${ }^{14}$, siendo este el primero que se conserva de esta tipología ${ }^{15}$. Posteriormente le seguirán otros como el de Juan de Roelas en la Capilla de Santiago de la catedral hispalense (1609). Anteriormente hubo otros como el de Pedro de Campaña en la también capilla catedralicia del Mariscal, (1555), con un inusitado dinamismo, al igual que el San Jorge y el dragón de la iglesia de Santa Ana, sobre los cuales sabemos hoy, gracias al profesor Valdivieso, que debieron realizarse sobre la misma fecha ${ }^{16}$. El Santiago de Campaña no es una pieza de gran tamaño como el de Alesio o el del Roelas, pero anticipa un vibrante dinamismo en la pintura sevillana.

Existen dos reformas del altar, una en 1679 y otra en 1789, cuando se restauró y se añadió decoración al retablo ${ }^{17}$. En época reciente se colocaron las imágenes de la Hermandad de la Redención: el Cristo y la Virgen del Rocío de Antonio del Castillo Lastrucci, determinando el traslado del lienzo de Santiago Matamoros que antes lo presidía al muro a los pies de la iglesia, donde se colocó tras la restauración.

Cabe mencionar que en el presbiterio hay pinturas murales con escenas de la vida de Santiago, hoy en pésimo estado de conservación, lo cual nos alerta de la necesidad de una restauración para fijar el muro y evitar que se arruine por completo. Estas pinturas han sido atribuidas por López Martínez a Matías de Arteaga, fechándolas a fines del s. XVII. Arteaga es autor también de varias copias de retratos de Argote; además, pudo haber recibido el encargo de restaurar la capilla que se documenta en el XVII. Argote redactó una corta autobiografía dedicada a su hijo para colocarla en su capilla, la cual no sabemos si llegó a figurar ${ }^{18}$, pero lo que sí figura es una modesta lápida que aún subsiste y reza así:

"ESTA CAPILLA MAYOR I EN - ENTIERRO ES DE GONÇALO AR - GOTE DE MOLINA PROVIN - CIAL DE LA HERMANDAD - DEL ANDALVZIA Y BEINTE - I QVATRO QVE FVE DE SEVI - LLA Y DE SVS HEREDEROS. - ACABOSE AÑO DE 16OO."

${ }^{14}$ FERNÁNDEZ LÓPEZ, José: Programas Iconográficos de la Pintura Barroca Sevillana del siglo XVII. Sevilla, Universidad de Sevilla, 2002, p. 21.

${ }^{15}$ PALOMERO PÁRAMO, Jesús M. El retablo sevillano..., op. cit., p. 307.

${ }^{16}$ Gracias a un boceto común a las dos imágenes que se conserva en el Metropolitan de Nueva York; VALDIVIESO, Enrique: Pedro de Campaña, Sevilla, Fundación Endesa, 2008, pp. 111 y 196, n.122.

${ }^{17}$ PALOMERO PÁRAMO, Jesús M., El retablo sevillano..., op. cit., p. 308.

${ }^{18}$ Ibidem, p. 163. 
En un primer análisis iconográfico del cuadro encontramos los diferentes elementos y personajes que lo conforman. Ya en los Privilegio de los Votos, Santiago porta una gran bandera blanca (maximun vexillum album) como un importante atributo que es interpretado por cada artista a su manera. Son pocos los que lo representan con una bandera del tipo 'gonfalón' terminado en dos, tres o cuatro puntas de tradición medieval, aquí con la cruz santiaguista o de puñal. El estandarte le confiere un estatus superior al de los demás caballeros, ya que este equivalía a llevar una fuerza de cincuenta lanzas ${ }^{19}$, y además simboliza el patronazgo de Santiago sobre la nación española y el triunfo de Cristo sobre los enemigos de la fe. A esto se añade la significación del blanco como la pureza y claridad del guerrero, sustentador de la fe sin contaminarse de las herejías.

Otro elemento importantísimo en la iconografía de Santiago es la espada, atributo que nunca falta, ya que la institución es una orden de caballería, es decir militar, también llamada Orden de Santiago de la espada. Desde sus comienzos fueron nombrados en los documentos latinos como fratres de spata. Recuérdese, además, que el atributo característico durante la Edad Media de Santiago el Mayor como apóstol es la espada, en recuerdo de su martirio y decapitación. Pero para la orden, la espada es el símbolo de las cuatro virtudes cardinales: fortaleza, prudencia, temperancia y justicia, relacionadas estas con las partes de la misma como indica las reglas de la misma ${ }^{20}$. Esta espada como símbolo de guerra religiosa tiene un evidente paralelismo con la del rey san Fernando, pues la crónica cuenta que Juan II, siendo infante, fue a honrar la espada, besar la mano y el pie de san Fernando. ${ }^{21}$

El caballo blanco es, sin duda, el más popular de los elementos identificativos desde los textos más antiguos: videbitis me constanter in equo albo, (me veréis constantemente en un caballo blanco). Esta característica de Santiago se mantiene desde las primeras representaciones medievales hasta nuestros días. Un héroe medieval tenía que ir a caballo, símbolo del estatus y de superioridad, como venía ocurriendo desde la más remota antigüedad. Así lo evidencian desde los relieves del arte rupestre sasánida hasta Grecia y Roma, donde el jinete aparece en actitud de aplastar al enemigo que cae a los pies del caballo.

Pero también considero obligado añadir otro santo que repite la misma iconografía y está datado de la misma época ${ }^{22}$. Se trata de un santo musulmán que, a lomos de un gran caballo blanco porta una bandera: el Mahdi, que blandiendo una gran espada vendrá para separar los buenos de los malos, dispuesto a

${ }^{19}$ CIEZAR, Nicolás: Santiago Matamoros, historia e imagen, Málaga, Servicio de Publicaciones, Diputación de Málaga 1999, p. 28.

${ }^{20}$ Ibídem, p. 31; Regla Edición de 1655, f. 66.

${ }^{21}$ Crónica de Juan II, Madrid, Biblioteca de Autores Españoles, ed. Cayetano Rosell, 1953, t. 68, p. 301.

${ }^{22}$ CABRILlANA CIEZAR, Nicolás: Santiago Matamoros..., op. cit., p. 41. 
defender a sus creyentes. Los estudios sobre este santo aducen las leyendas recogidas por los sufíes en 1141. Pero además sabemos que el propio profeta Mahoma también prefería montar sobre una yegua blanca.

Los moros simbolizan el mal, los temores de los cristianos en una época de gran inseguridad. Simulando así un gran triunfo de lo bueno sobre lo malo que, aunque no deje de ser una simbología maniquea, es precisamente lo que le confiere mayor calado dentro del inconsciente colectivo. Los moros representan, en suma, a los enemigos de la fe católica y en la iconografía de la época son representados como el símbolo del antagonismo religioso: seres fanáticos deformes y monstruosos, ya que la belleza física se consideraba expresión de la belleza moral, llevando al enemigo a su identificación con los demonios.

Otros elementos iconográficos se esclarecen recurriendo a la obra literaria e historiográfica de Argote en su Nobleza de Andalucía, donde el autor menciona el encargo del lienzo a Pérez de Alesio. Aquí añade el entronque de su familia con los protagonistas de la batalla, haciéndoles partícipes, lo cual se visualiza en el cuadro a través del emblema de los Villalobos -dos lobos pasantes-, representado en el estandarte que aparece en primer lugar ${ }^{23}$ (figura .2). El mismo elemento heráldico de los lobos aparece también en el escudo de armas de Argote, por lo que se cree que la familia Villalobos debió entroncar con la de Argote, cuyo escudo aparece representado en el prólogo de la Nobleza de Andalucía ${ }^{24}$. Cuentan las crónicas que la bandera de Clavijo, a la que se conoce también como la 'Seña' o la 'Enseña', fue portada en el año 844 por el alférez del Rey Ramiro I, Luis Osórez, señor de Villalobos, en la contienda contra las tropas de Abderramán II en Clavijo. En el siglo XV fue cedida al municipio de Astorga con la condición expresa de que fuese portada en procesión hasta la catedral todos los años el día de la Asunción, para ser recibida por el cabildo, al que el marquesado debía abonar 60.000 maravedíes $^{25}$. En la actualidad se conservan algunos fragmentos originales de dicha bandera, en una arqueta de madera forrada de terciopelo rojo, junto a documentos que acreditan su legitimidad. En la bandera se representan,

23 "Vefe pintada efta batalla de excelente pintura de mano de Matheo de Alecto Pintor de fu Santidad en Sevilla en la Capilla Mayor de la Iglefia de Sanctiago Enterramiénto de mis abuelos, donde fe veen en ella las Armas defte Image en tu Vádera. En la ciudad de Baeça fue dado en repartimiento a Cavalleros defte apellido de Villalobos el Cerro de Villalobos, cuyo linage duró muchos anos en el Reyno de Jaen principalmente en la ciudad de Vbeda, donde en el Padron de los hijosdalgo del año 1446. ay hijosdlago defte apellido. Sus armas son lobos negros en campo de plata.", ARGOTE DE MOLINA, Gonzalo: $L a$ nobleza del Andalvcia, Sevilla, Fernando Díaz, 1588, fol. 118v. También hace referencia López Martínez a los lobos del escudo "por su valeroso comportamiento en la batalla"; LÓPEZ MARTÍNEZ, Celestino: Capítulos para la biografia ..., op. cit., p. 160.

${ }^{24}$ Ibidem, p. 160, n. 1.

${ }^{25}$ RODRÍGUEZ DÍAZ, Matías: Historia de la muy noble. leal y benemérita Ciudad de Astorga, Valladolid, ed. Maxtor, 2008, p. 266. 
sobre fondo amarillo, dos lobos pasantes de color rojo y se encuentra bordeada de triángulos rojos y azules.

Argote se vincula con la acción de sus antepasados mediante su propia participación en la Guerra de las Alpujarras. Esta vocación santiaguista de Argote es la que le lleva a dotar a la iglesia de Santiago el Viejo de Sevilla, escogerla como su sepultura y la de su linaje, puesto que su antepasado, como recoge Pacheco ${ }^{26}$, tomó la ciudad de Córdoba a los moros ${ }^{27}$. Esta capilla ya tenía un enterramiento, el de la familia Mendoza, que también era familia de Argote por parte de madre, así que dotó a la iglesia cuya capilla había heredado.

Dicha participación en la guerra de la Alpujarra contra los moriscos, en la que lucharon en las galeras dirigidas por Sancho de Leiva para impedir la ayuda a los sublevados del norte de África, fue en representación de Francisco Hurtado de Mendoza ${ }^{28}$; pero el conocimiento que los moriscos tenían de las costas hicieron ineficaz este trabajo como cuentan las crónicas ${ }^{29}$. También ayudaron con las galeras al ejercito del Duque de Arcos en la serranía de Ronda, donde los encuentros con los rebeldes fueron muy frecuentes, siendo algunos de ellos en las playas de Manilva y Fuengirola ${ }^{30}$, en las cuales participaría seguramente Argote ${ }^{31}$. También lo hizo en el traslado de los moriscos para su control, en el embarque que llevara a cabo don Sancho de Leiva de los moriscos desde Almería hasta Sevilla. No es de extrañar, como apunta Cabrillana, que hubiera un productivo intercambio de ideas entre Argote y Alesio, influyéndole con sus narraciones de la guerra con los moriscos y los contenidos iconográficos que de esta se derivan ${ }^{32}$.

Con respecto a la tercera figura, la del soldado vestido a la romana, es decir con coraza, falda corta y borgoñota con penacho; no nos cabe la menor duda

${ }^{26}$ PACHECO, Francisco: Libro De Descripción De Verdaderos Retratos.., op. cit., p. 273.

27 "Figura el escudo de "DOMINGO MVÑOZ Y MARÍN Ruyz de Argote, y Pero Ruyz Tafur con los Cavalleros de la frontera ganá de los Moros el Axarquia de Cordova, y el rey de la ciudad. cap., XCV. En el año 1235, con la ayuda de los hijos dalgo Adalides y Almogavares, de la frontera con Córdoba, como tras capturar algunos moros notaron que la ciudad estaba descuidada y sin miedo a los cristianos, por lo que decidieron hacer esta empresa", ARGOTE DE MOLINA, Nobleza de Andalucía.., op. cit., libro 1, cap. 98.

${ }^{28}$ MÁRMOL CARVAJAL, Luis del: Historia del rebelión y castigo de los moriscos del Reino de Granada. Madrid, B.A.E., 1946, t. 21, pp. 228 y ss.

29 "Acudían a este tiempo, a todas horas, navíos de berbería a nuestras costas, cargados de bastimientos, gente, armas y municiones que los moros andaluces, que habían pasado a tetuán y Argel procuraban enviar a los alzados." MÁRMOL CARVAJAL, Luis del: Historia del rebelión..., op. cit., p. 348.

${ }^{30}$ Ibídem, p. 120

${ }^{31}$ CABRILLANA CIEZAR, Nicolás: Santiago Matamoros..., op. cit., p. 146.

${ }^{32}$ Manuel de Carvajal publica en 1600 un libro donde recoge relatos que circulaban por pueblos y reinos de Granada desde los años de la guerra; CABRILLANA CIEZAR, Nicolás: Santiago Matamoros..., op. cit., p.149. 
que se trata de san Miguel (fig.ura 3), como supuso Cabrillana y como incita a creer Argote : “.. del Apóstol Santiago y del glorioso san Miguel y del Sancto rey Don Fernando a quin yo tengo por abogados..."33; y "Tomó por armas la ciudad de Ubeda la imagen del arcángel san Miguel, por que refieren que tal día fue ganada a los moros..." ${ }^{4}$. Además, formalmente, esta figura rememora el San Miguel que Alesio pintara en la Capilla Sixtina, concretamente en la figura del santo que desciende del cielo en medio de otros dos ángeles que portan sendas espadas, vistiendo la coraza ceñida a la romana de color amarillo, con detalles en la cintura y el pectoral de color azul. Levanta una lanza en la mano derecha mientras que alarga el brazo izquierdo en actitud de ataque contra los demonios que intentan robar el cuerpo de Moisés, lo cual contrasta con su gesto sereno. La figura esta completada con los atributos característicos de todo ángel. Seguramente esta figura formaría parte de los dibujos y bocetos que trajo Alesio a su llegada a Sevilla y con los que se defendió de los ataques de los artistas locales como Jerónimo Hernández, cuya anécdota recoge Pacheco y que además fue usada por el italiano para presumir de su condición de artista del Sumo Pontífice. Se trata de un dibujo que, con pocas modificaciones del original, ha sido representado en la parte inferior izquierda, donde vemos que porta una borgoñota menos fantasiosa que la romana y, quizá inspirada en la colección de armas del museo de su mentor. En el Ecce Homo del Oratorio del Gonfalone, el soldado que observa la escena porta una borgoñota plumeada parecida de su amigo y mentor Cesare Nebbia, y también la llevan los soldados en la Coronación de espinas de su también maestro y colaborador Federico Zuccaro.

El brazo izquierdo aparece en actitud de apartar un elaborado escudo para atacar al enemigo y sobre el hombro izquierdo reposa una capa verde. La figura de la Sixtina tiene una de color morado, lo cual nos lleva al uso de la teoría del color, pues ello forma parte del ejercicio de la perspectiva, ayudando al efecto de retrasar el hombro que se encuentra más alejado y consiguiendo así más credibilidad en el escorzo de la figura. El pie izquierdo se adelanta en ambas figuras en pos del escorzo y porta los característicos coturnos que eran considerados en el

33 "En la ciudad de Seuilla Jueves XX dias del mes de Noviembre de 1572 años \| yo Gonçalo Çiatico de Molina con deseo de hazer algún seruicio || a esta ciudad Mi Patria. He recogido y ajuntado las $\|$ Relaciones preuilegios y Antigüe- dades en este libro contenidas || Para escreuir la Crónica de seuilla con Ayuda de nro. Sor $\|$ en cuyo nombre este libro se empieza y de nra. S» la \|| virgen maria y del apóstol Sanctiago y del glorioso sa[n]miguel $\|$ y del sancto rey don feman- do a quien yo tengo por abogados. El Principio es el Medio de Todas las cosas.-MS. original en 81 fojas de a fol. (de las cuales, están paginadas las 10 primeras de mano del autor, y las restantes están por foliar). De ellas sólo están es- critas o tienen algo escrito unas 43; las demás están en blanco". B. J. GALLARDO: Ensayo de una biblioteca española de libros raros y curiosos, I, núm. 258. Ed. Gredos. 1968; PALMA CHAGUACEDA, Antonio, El Historiador Gonzalo Argote..., op. cit., p. 73.

${ }^{34}$ ARGOTE DE MOLINA, Gonzalo: La nobleza del Andalvcia..., op. cit., lib. 1, cap. 8. 
clasicismo como ropa divina y que caracteriza a los ángeles en el Renacimiento y el Barroco. Es especialmente identificativo en la indumentaria del arcángel, aunque también se observa en otros personajes como el rey David que Alesio realiza en el Oratorio Gonfalone, -con idénticos coturnos que el ángel de la Sixtina.

Los detalles de la armadura coinciden con pocas modificaciones en las dos figuras, la de Roma y la de Sevilla, pero el gesto sereno se troca en Sevilla en un gesto de esfuerzo; la mirada entornada y decidida de Roma se llena de ira en Sevilla; el interés de representar la emoción esta patente. Forma parte de esta nueva manera de entender el arte que ya empieza a verse en Alesio.

El principal papel del arcángel san Miguel es el de guerrero espiritual, el enemigo de Satanás, y su nombre significa 'Quién como Dios'. Es el Jefe de los Ejércitos de Dios en las religiones judía, islámica y cristiana. Según I Tesalonicenses 4,16 , tocará la trompeta el día del arrebatamiento. Su nombre se menciona tanto en el Antiguo Testamento como en el Nuevo. Se le representa con armadura de guerrero o de soldado centurión y casi siempre lleva una espada o una lanza con que vencer a su enemigo ${ }^{35}$

Tanto a nivel literal como simbólico, el arcángel Miguel representa la justicia y la lucha por el bien, de ahí la simbología básica entre cristianos y musulmanes, estos últimos representados muy similares a los demonios que pintó en la Capilla Sixtina.

En el Corán, Miguel es llamado Mījāî̄il o Mijal (لبئاخيم). Se le menciona en la azora 2:98, y en la 11:72 y 11:69, especificando que era uno de los tres ángeles que visitaron a Ibrahim (Abraham) para anunciar el nacimiento de Isaac y Jacob. Para los musulmanes Miguel es uno de los cuatro arcángeles (con Izrail, Israfil y Yibril) y uno de los dos ángeles con Gabriel.

El escudo. Aunque se habla del carácter antimusulmán del cuadro, hay detalles que no pasan desapercibidos, como que Argote se preocupara de que Alesio decorara con una bella grafía árabe el primer escudo que aparece representado en el cuadro, donde se reproduce siete veces la misma frase de inspiración coránica: Allah (Solo Alá es vencedor) ${ }^{36}$ (figura 4). Esta frase forma parte del lema de los reyes nazaríes, el cual encontramos reproducido en los salones de la Alhambra, de la madraza y otros monumentos granadinos pero, en contra de la opinión de Cabrillana, creemos que no se representa como forma de desprecio, sino de conocimiento, pues es sabido que Argote en

${ }^{35}$ CARMONA MUELA, Juan: Iconografía de los santos. Madrid, Akal, 2003, pp. 328-332.

${ }^{36}$ CABRILlANA CIEZAR, Nicolás: Santiago Matamoros..., op. cit., p. 153. 
su librería tenía varios ejemplares manuscritos en lengua árabe y otros tantos traducidos ${ }^{37}$ y además él mismo recogió algunas canciones moriscas ${ }^{38}$.

Profundizando algo más en el emblema, Pavón Maldonado ${ }^{39}$ aclara la confusión histórica sobre este motivo, resultando ser el escudo de la orden de la Banda, instituida por Alfonso XI en el año 1331 y que tomará como modelo Muhammad V, por su amistad con el rey Don Pedro, siendo éste realizado de mano de artistas toledanos.

Argote de Molina afirma que Ibn al-Ahmar usó por armas en sus escudos reales la bandera bermeja en letras árabes ${ }^{40}$ como hoy se ven dentro del palacio Real de la Alhambra, en el Cuarto de los retratos de los Reyes Moros, en las doblas de oro que corrieron en el reinado de Granada y en su divisa ${ }^{41}$. Hurtado de Mendoza lo describe de forma diferente, como dorado en campo rojo ${ }^{42}$. Pero

${ }^{37}$ En la biblioteca de Argote había: "Libro de Philosofía, en castellano, fecho por Abnali Hamete Benmozoïa el Abiani, por mandado del rey Alphonso el Sabio. - Propiedades de todas las piedras por Hamete Benzaide, (léase Abu-Ali-Ben Miscawaih o Micuya (+ 421 de la hégira o 1030 de J.C.). - Un libro en arábigo, que dicen es Crónica de España, fecha por mandado de Rasis. - Libro de filosofía escrito por el moro Avicena." PALMA CHAGUACEDA, Antonio: El historiador Gonzalo Argote..., op. cit., pp. 223-235; Otro listado más completo lo ofrece PEPE, Inoia: "La bliblioteca di Argote de Molina, tentativa di catalogo della sezione manoscritti”. Studi di Letteratura Spagnola. Roma, 1967, pp. 165-262. Dice así: "Vn libro en arábigo, que dicen es Crónica de España fecha por: mandado de Rasis . Historia de España escrita en arábigo por Rasis, rey de Córdoba; i Majomart Avicena Historia de España de los Moros hecha por tres Arabes: Rasis; Mahomad, y el Alto Bucar ; Otra "storia di Spagna", por Rasis, Rey de Córdova, y Mahomet y el Alto Bucar, en Arabe, con su traducción en Castellano; Libro de concilios de España escrito en pergamino, en letra y lengua arábiga, por Juan Obispo de Sevilla, siendo Sevilla de moros = Concilios de España en Arabe por luán, Arzobispo de Sevilla, en tiempo de los Moros".

${ }^{38}$ LÓPEZ MARTÍNEZ, Celestino: Gonzalo Argote de Molina historiador..., op. cit., p. 202.

${ }^{39}$ PAVÓN MALDONADO, Basilio: "Escudos y reyes en el Cuarto de los Leones de la Alhambra", Al-Andalus, vol 35, n.1, Granada, 1970, p.179

40 "...Y hizo las señales de sus Armas en Escudo negro Vanda de oro con letras árabes...", ARGOTE DE MOLINA, Gonzalo: Nobleza de ..., op. cit., p. 97.

${ }^{41}$ PAVÓN MALDONADO, Basilio, Escudos y reyes..., op. cit., p.179.

${ }^{42}$ Ibn al-Ahmar, inaugurador de la dinastía nazarí, acompañó en concepto de vasallo a san Fernando en la conquista de Sevilla y recibió de este sus armas y su escudo: "dióle el cristiano, por estandarte para el y los que fuesen reyes de Granada la Banda de oro en campo rojo con dos cabezas de sierpes a los cabos, según traen en su guión los reyes de Castilla, añadió él las letras azules que dicen: (no hay otro vencedor que Dios)." HURTADO DE MENDOZA, Diego: Guerra de Granada que hizo el Rey D. Fernando contra los moriscos de aquel reino sus rebeldes. Madrid, 1610, libro $2^{\circ}$, p. 119. 
existe alguna confusión en los datos de que Argote disponía ${ }^{43}$, ya que sabemos que conocía esta amistad cristiano/musulmana que da origen al emblema, y que fueron los ejércitos de la banda los que ayudaron a Muhammad V a recobrar su trono granadino en 1362, mientras que en 1368 las tropas de Muhammad V auxiliaron a las de don Pedro para recuperar Córdoba. Estos datos testimonian la amistad entre Muhammad V y el rey Don Pedro, siendo este el verdadero fundador del escudo nazarí de la banda, al cual le añade el emblema: 'solo dios es vencedor' y le cambia los colores. De esta manera, el escudo de don Pedro pasa a ser modelo del nuevo escudo nazarín ${ }^{44}$.

Dicho lema es el que figuró en los estandartes almohades desde el día que Abú Yusuf al-Mansùr vence en Alarcos a los cristianos en 1195, y después Ibn al-Ahmar, al hacerse dueño de Granada en 1238, lo adopta por enseña ${ }^{45}$ apareciendo 'sólo dios es vencedor' en todas las paredes de la Alhambra y de Granada.

Pero en este punto la lectura iconográfica se nos complica. Para Lafuente Alcántara el lema y la bandera se remontan a la batalla de Alarcos, donde, según la leyenda, habían sido ondeados por un ángel en un caballo blanco, como el propio Santiago:

“...apareció en los espacios un ángel montado en un caballo blanco, tremolando una bandera, que se extendía de polo á polo, en la cual se leían las mismas palabras: Wa le Galib ile Alá; y que semejante aparición fue el anuncio de la victoria..."46.

Podría estar recogiendo el historiador la leyenda paralela de el Mahdid"47, el santo musulmán a lomos de un gran caballo blanco y portando una bandera que, blandiendo una gran espada, vendrá para separar los buenos de los malos;

43 "El rey Abullale rey de Sevilla entregó trescientos mil mrs de plata por tregua de un año, y otorgosela el rey. El Rey fue contra jaén, que era en aquella fazon de Abenhuc rey de Granada, Murcia, y Almería, Moro valeroso que en el castillo de Ricot en Murcia se había levantado contra los Almohades, que eran Africanos, y trataván cruelmente a los Moros Españoles, y juntando ejercito con ellos paso a cuchillo, y y conquisto todo el Reyno de Murcia, Granada, y Almería, excepto Valencia... Era este Abenhuc de linaje de Abenalfange, y por su esfuerzo y bondad valió mucho, y fue buen Rey esforzado y justiciero...", ARGOTE DE MOLINA, Gonzalo: La nobleza del Andalvcia..., op. cit., p. 97.

${ }^{44}$ PAVÓN MALDONADO, Basilio: Escudos y reyes..., op. cit., p.187.

45 ALMAGRO CÁRDENAS, Antonio: Inscripciones árabes de Granada, ed. Extramuros, Sevilla, 1879, pp. 20-21; PAVÓN MALDONADO, Basilio: Escudos y reyes..., p.187.

${ }^{46}$ LAFUENTE ALCÁNTARA, Miguel: Historia de Granada, comprendiendo la de sus cuatro provincias Almería, Jaén, Granada y Málaga, desde remotos tiempos hasta nuestros días. vol. 2, París, Baudry librería Europea, 1852, p. 65.

${ }^{47}$ CABRILLANA CIEZAR, Nicolás: Santiago Matamoros..., op. cit., p. 41. 
según las leyendas recogidas por primera vez por los sufíes en $1141^{48}$. Tal leyenda es aprovechada por los emires con ansias de poder como Ibn Tumart en el siglo XII, fundador de la dinastía almohade, por lo que no es de extrañar que se usara como emblema para la lucha contra los cristianos.

Los escudos de formas caprichosas responden al espíritu manierista del artista que, como hemos visto, contienen emblemas y funcionan como tarjas ${ }^{49}$. Podemos ver algunos escudos extraños de este tipo en las figuras alegóricas insertadas en las pinturas del XVI, decorando los fondos arquitectónicos ${ }^{50}$. Alesio vería estas formas cuando trabajó en la Sixtina, a lo que sumándole su experiencia en Malta (donde seguro que vería los escudos de la armada turca que representa en sus frescos, grabados y pinturas de El asedio de Malta), hace una mezcla deliberada de ambos conceptos: el fantasioso ideal como tarja, soporte de un emblema, y la forma curva de los escudos de Malta, añadiéndole a estos unas volutas en las esquinas y dándole así un cuerpo más estilizado. El escudo de tres lunas de plata sobre banda verde en fondo rojo, se corresponde con la bandera del imperio otomano en el siglo XVI, justo al contrario de como aparece en el escudo tarja de la imagen.

El Emir (figura .5). La historia resalta la amistad entre el rey cristiano y musulmán, tanto que el primero levanta un palacio de factura musulmana donde se lee 'Gloria a nuestro señor el Sultán Don Pedro'. Muhammad V a su vez envía al Alcázar de Sevilla alarifes granadinos y don Pedro le envía artistas del yeso y pintores mudéjares toledanos a decorar los nuevos palacios de la Alhambra entre

48 "El Mahdí, "el guiado", aunque no se menciona el en Corán, ha jugado un importantísimo papel en la historia islámica, algunos consideran a Jesús como el Mahdí, tan importante en la ortodoxia como en la creencia popular, es el iniciador del juicio final.", BLEEKER, Claas Jouco y WIDENGREN, Geo: Historia religionum, Manual de historia de las religiones. vol. 2, Madrid, Ediciones Cristiandad, 1973, p. 186; Encyclopadia Britannica Online, s. v. "mahdi", http://www.britannica.com/EBchecked/topic/358096/mahdi. (consultado el 30/10/14).

${ }^{49}$ Tarja (del fr. targe): escudo grande que cubría todo el cuerpo, y más especialmente la pieza de la armadura que se aplicaba sobre el hombro izquierdo como defensa de la lanza contraria. http://www.rae.es/. edición n ${ }^{\circ} 22$ y las enmiendas incorporadas hasta 2012. Consultado el 20-11-2014. Idéntica definición encontramos en FATÁS, Guillermo y BORRÁS, Gonzalo: Diccionario de Términos de Arte y elementos de Arqueología, Heráldica y Numismática. Madrid, Alianza Editorial, 1993, p.224.

${ }^{50}$ Por ejemplo, en las estancias vaticanas. En el fresco de la Escuela de Atenas (Sala del Sello), en su parte superior derecha, observamos una la figura de Palas Atenea que sostiene un escudo de forma caprichosa, decorada con una cabeza de medusa. En la Sala de Constantino, en el fresco de La batalla del puente Mulvio, cuyo boceto original es de Rafael. En él vemos a un hombre que huye cruzando el río, cubriéndose la cabeza con un escudo-tarja, también con una forma caprichosa. 
1364 y $1369^{51}$. Esta amistad revela una relajación en las costumbres musulmanas de la península, de ahí que existan pinturas figurativas en el techo del Salón de la Justicia de la Alhambra. El historiador africano, Ibn Jaldun, que vivió en los palacios de la Alhambra como invitado de Muhammad V, relata en su biografía que visitó al rey don Pedro en Sevilla, en el año 1363, criticando esa convivencia con los cristianos en sus crónicas ${ }^{52}$.

El Emir que aparece destacado de los demás moros que huyen al que hace referencia López Martínez ${ }^{53}$, podría ser el retrato de un rey Alhamar, que aparece en la bóveda central de la Sala de la Justicia de la Alhambra, pinturas que seguro Argote vio en sus muchos viajes y de las cuales habla Hurtado de Mendoza como reyes granadinos, según fundación de Muhammad I ${ }^{54}$. Esta dinastía que coopera con los reyes cristianos, como cita Argote en su Nobleza, obtendrá por ello su escudo de la mano del rey don Fernando ${ }^{55}$.

Al contemplar la fisionomía del santo, nos hemos detenido en su nariz y sus vivos ojos, nos hemos fijado en el triángulo que componen el rostro: ojos-nariz. Dicho triángulo suele permanecer de alguna manera invariable durante el paso del tiempo en los rostros humanos ${ }^{56}$. Cabrillana opina que el rostro de Santiago podría ser un retrato de Argote, y lo secunda López de Sedano, quien lo describe a la vista de un cuadro que poseía el Conde del Águila, pintado por Matías Arteaga, del que inserta un grabado ${ }^{57}$ y la dicha descripción física ${ }^{58}$.

${ }^{51}$ PAVÓN MALDONADO, Basilio: Escudos y reyes..., op. cit., p.188.

52 "En nuestros días, los andaluces imitando a los cristianos se visten como ellos, emplean sus emblemas y muchas de sus costumbres, que aparecen en las pinturas con representaciones figuradas sobre los muros de sus edificios y habitaciones." IBN JALDÚN, Abderrahmán: "al-Muqaddima", en Actas de las II Jornadas de Cultura Árabe e Islámica, Madrid, Instituto Hispano-Árabe de Cultura, 1985, p. 438.

${ }^{53}$ LÓPEZ MARTÍNEZ, Celestino: Capítulos para la biografí..., op. cit., p. 160.

${ }^{54}$ HURTADO DE MENDOZA, Diego de: Guerra de Granada..., op. cit., p. 119; PAVÓN MALDONADO, Basilio: Escudos y reyes..., p. 179.

55 "Abenhuc rey de Granada, Murcia, y Almería, Moro valeroso que en el castillo de Ricot en Murcia se había levantado contra los Almohades, que eran Africanos, y trataván cruelmente a los Moros Españoles, y juntando ejercito con ellos [...] Era este Abenhuc de linaje de Abenalfange, y por su esfuerzo y bondad valió mucho, y fue buen Rey esforzado y justiciero. Y hizo las señales de sus Armas en Escudo negro Vanda de oro con letras Arabes.” ARGOTE DE MOLINA, Gonzalo: Nobleza de Andalucía..., op. cit., p. 97.

${ }^{56}$ Actualmente para detectar e identificar los rostros se usan los algoritmos de detección de caras que, desarrollados originariamente para las cámaras de seguridad y para la investigación forense, se basan en ciertos puntos determinativos del rostro.

${ }^{57}$ LÓPEZ DE SEDANO, Juan Joseph: Parnaso español. Madrid, Don Antonio de la Sancha, 1778, vol. IX. en PALMA CHAGUACEDA, Antonio, El historiador Gonzalo Argote...op. cit., p. 52.

58 "fue un hombre de mediana estatura, no muy recio, aunque robusto de miembros y el rostro abultado, la frente espaciosa, los ojos alegres y vivos, como ingenioso y esforzado; 
Hemos superpuesto, en un ejercicio gráfico, el retrato de Argote procedente del libro de Retratos Ilustres de Pacheco, considerado por Chaguaceda como el más verídico (puesto que Pacheco debió conocer a Argote en persona) y observamos que coinciden con precisión los rasgos básicos de ambos retratos, pudiendo con mucha certeza suponer que son la misma persona. Es decir, que Alesio representa al santo con las facciones de Argote. La fisonomía del rostro tan peculiar de Argote, nos hace reconocer rápidamente el parecido del dibujo de Pacheco con el de Alesio. El de Pacheco con el atuendo militar, el pelo y la barba cortos nos hacen pensar en un Argote joven, por lo menos antes de abandonar las armas para el ejercicio de las letras, que sería el Argote que retrata Alesio. El rostro de nariz afilada y ojos vivos, que describe López de Sedano, tiene la mirada perdida hacia la parte superior del cuadro, hacia una zona que creemos desaparecida. López Sedano lo describe con barbas, cabellos largos y bien puesto, lo que correspondería más a la pintura que al dibujo. Los nexos de similitud están en la nariz y en los ojos del mismo, de tal forma que nos propusimos cotejarlos y para nuestra sorpresa resultó que ambos retratos coinciden exactamente, el dibujo de Pacheco con la pintura de Alesio, realizada más de treinta años después (fig.6).

Resulta llamativo como los retratos de las dos figuras de santos, san Fernando y Santiago, aparecen enmarcados con una capa flotante al estilo de orla (fig.7), que matiza ambos retratos, como si el autor quisiera destacarlos del fragor de la batalla. Esta forma de enmarcar las figuras es heredera de la tradición romana; recordemos el Ara Pacis Agustae, que justamente en la época que Alesio se encontraba en Roma, estaba en fase de excavación, habiéndose documentado unos bocetos de fines del siglos XVI y de autoría anónima ${ }^{59}$. El gran interés artístico e histórico que estos restos arqueológicos tenían como un testimonio de la grandeza clásica, era además un interés de tipo didáctico. Muchos artistas dejaron constancia evidente de esos débitos a los restos antiguos en sus obras. Puede ser este uno de esos guiños a la antigüedad o puede que lo usara como símbolo para resaltar una divinidad, como se hacía en época clásica, creando una orla, lo cuál justificaría la teoría de que el rey Ramiro no es otra cosa que la imagen de san Fernando elevado a la santidad. Dicha santidad era defendida en esa época desde la ciudad de Sevilla y sus círculos intelectuales aunque todavía no era reconocida oficialmente.

el aspecto agradable y majestuoso...[..]Las virtudes de su ánimo correspondían a las que denotaban su aspecto, principalmente las del valor la magnanimidad, la constancia y la piedad cristiana.", PALMA CHAGUACEDA, Antonio: El historiador Gonzalo Argote... ,op. cit., p. 53; CABRILLANA CIÉZAR, Nicolás: Santiago Matamoros..., op. cit., p. 150.

${ }_{59}$ Siete dibujos de un artista anónimo, elaborados sobre 1568-1580. Estos dibujos constan de siete folios 93-96 del Ursinianus Codex Ligorio y Panvinius, anteriormente en los Uffizi, ahora en la colección del Vaticano (cat. no. 3439). 
Pero las influencias de Alesio suelen ser más directas, como buen tardomanierista, acudiendo casi siempre a fuentes ya existentes más cercanas como son grabados o bocetos que el mismo realizó y llevaba en su equipaje. Así ocurre con la imagen del dibujo conservado en el Metropolitan de Nueva York, procedente de la escuela de Miguel Ángel y fechado en la primera mitad del XVI, donde observamos el mismo manto y la misma disposición central de la figura que la del rompimiento de gloria del grabado de Alesio alusivo a san Pablo.

Argote declara en repetidas ocasiones tener por abogados al Santo Rey Don Fernando y al Glorioso San Miguel, además de Santiago ${ }^{60}$. En la Nobleza cuenta Argote que es descendiente de Martin Ruiz de Argote y que consta en la crónica del rey don Fernando, ganando a los moros la ciudad de Córdoba y muriendo posteriormente en la guerra ${ }^{61}$. Es por esto que el rey representado tras el santo ha sido interpretado por algunos autores más como san Fernando (fig.8) que como Ramiro I. Si bien es verdad, la imagen del rey Fernando hasta esta época, guarda mucho mayor parecido con la representada en el cuadro de Alesio ${ }^{62}$ que con Ramiro I, como el del Tumbo A (s. XIII) de la catedral de Compostela o los dibujos de Fernando del Castillo de 1534, donde vemos que el rey Fernando es representado de mediana edad, barbado y castaño. Además es el segundo de la tríada a la que se encomienda Argote ${ }^{63}$.

En las representaciones posteriores, a partir de Pacheco, aparece un Fernando III más joven como en el lienzo de este de San Fernando entrando en Sevilla de la catedral hispalense, contratado en 1634. Ello conllevará todo un florecimiento de

${ }^{60}$ LÓPEZ MARTÍNEZ, Celestino: Capítulos para la biografia..., op. cit., p. 157.

${ }_{61}$ "Fernán Martínez de Argote, alguacil mayor de Córdoba, que se encontró en el ejército de Fernando III, el cuál fue heredado en esta ciudad, y siguiendo al infante don Sancho en contra del Rey Sabio luchó en batalla campal con Fernán Pérez Ponce junto a las murallas de Córdoba, y allí murió", como se lee en la crónica de Alfonso X, capítulo 75, LÓPEZ MARTÍNEZ, Celestino: Capítulos para la biografí..., op. cit., p. 135; ver también: "en el escudo Argote pone el de DOMINGO MVÑOZ Y MARÍN Ruyz de Argote, y Pero Ruyz Tafur con los Cavalleros de la frontera ganá de los Moros el Axarquia de Cordova , y el rey de la ciudad. Cap, XCV en el año 1235 [...] con la ayuda de los hijos dalgo Adalides y Almogavares, de la frontera con Córdoba, como tras capturar algunos moros notaron que la ciudad estaba descuidada y sin miedo a los cristianos por lo que decidieron hacer esta empresa", ARGOTE DE MOLINA, Gonzalo: Nobleza de Andalucía..., op. cit., p. 98.

${ }^{62}$ CINTAS DEL BOT, Adelaida: Iconografía del Rey San Fernando en la pintura de Sevilla, Sevilla, Diputación Provincial de Sevilla, 1991; SÁNCHEZ DE LEÓN FERNÁNDEZ, María Ángeles: "Iconografía del rey Fernando III en la Real Academia de Bellas Artes de San Fernando", Boletín de la Real Academia de Bellas Artes de San Fernando, $\mathrm{n}^{\mathrm{o}} 75,1992$, pp. 511-556, p. 529, lámina 13.

${ }^{63}$ Vid. supra. PALMA CHAGUACEDA, Antonio: El historiador Gonzalo Argote..., op. cit., p. 70. 
este motivo ya en el XVII ${ }^{64}$. Estas escenas históricas se irán incorporando siempre a la moda del momento, de forma que será habitual representarlo con bigote y perilla, que es como queda fijada la iconografía del santo y así continuará hasta bien entrado el barroco.

Los demonios (fig. 9). Entre las muchas importaciones que hace el artista de la Capilla Sixtina, está la de las caras y gestos de los moros que huyen o caen aterrorizados. Son las mismas caras que realizó Alesio frente a Miguel Ángel. En la Sixtina los demonios de Alesio huyen por la derecha de la obra a esconderse en una gran cueva; en Sevilla podemos ver al fondo cómo las tropas que huyen a lo lejos también van a una especie de cueva. El soldado que cae bajo el caballo e intenta cubrirse con su adarga, es una versión del demonio al que san Miguel va a clavar su lanza en el fresco romano, con casi la misma postura: la pierna derecha algo estirada hacia atrás y la izquierda flexionada hacia delante, mientras que alza el brazo izquierdo en actitud defensiva. El soldado de Sevilla parece mucho más forzado, el giro de la cabeza da la impresión de irreal; el de Roma mantiene dentro de lo forzado y manierista una pose más natural; los ojos muy abiertos y la boca en actitud de gritar son muy parecidas. En Roma el demonio parece sonreír, pero el soldado de Clavijo soporta con estupor el ataque del santo. Otra semejanza es la del soldado que huye detrás del emir, con ambos brazos hacia delante y recibiendo en la espalda una tremenda herida de lanza. La boca mostrando la dentadura; los enormes ojos abiertos y la nariz chata son muy semejantes a los demonios de Roma como el de la derecha que sostiene una serpiente y el de la izquierda que muerde unas cadenas con grilletes.

Otra figura interesante, aunque muy difícil de ver, es la de un personaje que con gesto de horror se echa las manos a la cabeza y da la espalda a la escena, lo que nos recuerda a la figura semioculta en la escena del fresco de Noé en el techo de la Sixtina. También en la barca de los condenados del Juicio final aparece otra figura con el mismo gesto de horror. En el fresco de Alesio, dos de los demonios que interfieren por el cuerpo de Moisés son, aunque más dinámicos y exagerados, muy parecidos. Hay una figura de Bronzino, denominada los celos o la sífilis en la Alegoría del triunfo de Venus (1540) realizado para Cosne I de Médici, donde en la mitad izquierda, como en penumbra, se observa una figura que repite el gesto de espanto.

En Sevilla se produce un cambio de estilo en el artista. Un salto cuantitativo en la composición: el manierismo romano se torna en esta obra hacia un abigarramiento y un claroscuro que antecede a otras maneras, predecesoras de un barroco que aún están por venir.

El caballo recuerda al pintado por Rafael en las Estancias Vaticanas, que seguramente circularía en grabados y pudo traer tras sus trabajos en Roma. Se

${ }^{64}$ VALDIVIESO, Enrique: Catálogo de las pinturas de la Catedral de Sevilla, Sevilla, Guadalquivir, 1978, p. 95. 
encuentra apoyado sobre sus patas traseras levantando las delanteras, una acción que en las artes ecuestres clásicas se denomina lèvade o courbette, si el caballo avanza en esta postura.

El santo no porta el estandarte, como cuentan las crónicas, puesto que sostiene con la mano izquierda las riendas del caballo, a las que Alesio da gran importancia. A partir de la popularización de los libros de emblemática en el Renacimiento, las bridas se relacionaron directamente con la Templanza ${ }^{65}$. Esto se debe a la relación de Argote de Molina con el capitán Pedro de Aguilar, quien por aquellos años publica el tratado de la Caballería de la Gineta $^{66}$, dentro del cual escribe un soneto que, según algunos autores, es la primera obra conocida de Argote $^{67}$. En el tratado, Pedro de Aguilar, muestra la manera de sujetar las riendas que gráficamente describe Alesio en el cuadro.

En el plano simbólico, la imagen del jinete dominando un caballo fue popularizada por Alciato como símbolo de gobierno en la edición de 1531 de su famoso Emblemata $X X X V^{68}$. El caballo es un símbolo común de la pasión desenfrenada en el Renacimiento ${ }^{69}$. Alciato, cuyo trabajo era muy conocido en España, ilustra un jinete sobre un caballo encabritado bajo el título "In Adulari Nescientum". El significado de esta imagen y el título: "A él no puede halagar", la explica Alciato y son comentadas ampliamente por Diego López en su Declaración magistral sobre las Emblemas de Andrés Alciato de 1615.

El caballo no sabe cómo halagar a su amo: "Trata a todos por igual, el tirará a todos menos a el que realmente sabe cómo mandar y gobernarle de una manera firme y decisiva", el caballo no respeta al caballero por su rango ni condición, sino por su capacidad, por lo que "el príncipe debe aprender este arte fundamental de la equitación, o será juzgado indigno de gobernar..."70.

Variaciones sobre este tema se encuentran en los emblemas recogidos de varias fuentes por Henkel y Schöne. Hay que destacar que el caballero es a menudo

${ }^{65}$ Las bridas o frenos del caballo, se traduce como una metáfora del control de las pasiones.

${ }^{66}$ AGUILAR, Pedro de: Tratado de la cavalleria de la gineta, Sevilla, Impresso por Iuã Rene, 1600; AGUILAR, Pedro de: Tratado de la cavalleria de la gineta, (edic. facsímil; Sevilla, Extramuros Edición, 2007.

${ }^{67}$ PALMA CHAGUACEDA, Antonio, El historiador Gonzalo Argote..., op. cit., pp. 65, 66; CABRILLANA CIEZAR, Nicolás: Santiago Matamoros..., op. cit., p. 152.

${ }^{68}$ ALCIATO, Andrea: Emblemas (ed. de Santiago Sebastián), Madrid, Akal,1993.

${ }^{69}$ PANOFSKY, Erwin: Tiziano, problemas de iconografía, Madrid, Akal, 2003, pp. 118-119;. WIND, Edgar: Misterios paganos del Renacimiento, Barcelona, Barral, 1972, pp. 145-147; GEORGE, Ferguson: Signos y símbolos en el arte cristiano, Londres, Oxford University Press, 1973, p. 20; LIEDTKE, Walter A: The Royal Horse and Rider, Painting, Sculpture, and Horsemanship 1500-1800, New York, Abaris Books, 1989, p. 42.

${ }^{70}$ LÓPEZ , DIEGO: Declaración magistral sobre las Emblemas de Andrés Alciato, 1615. Emblema XXXV. 
un príncipe o un rey. Estos tópicos los recogieron posteriormente los autores de tratados sobre caballería. En la emblemática de Alciato y otros de significado similar, el caballero controla un caballo encabritado de donde procede la figura de algunos de los retratos ecuestres de reyes, príncipes o militares, ya del siglo XVII.

La lèvade parece ser un caso especial dentro de la tradición de la doma de caballos, de alta maestría y dificultad en el mundo de la equitación, constituyendo el más representativo y excepcional desde que la Haute École definió el arte de montar a caballo. Aparecen entonces, en algunos retratos reales y especialmente en los de la corte española. La imagen de Alciato fue refinada para satisfacer los nuevos estándares de equitación aristocráticos del siglo XVII. Unas imágenes que fueron adoptadas por artistas posteriores adaptándose así a las cambiantes situaciones políticas y sociales ${ }^{71}$.

Hemos encontrado en el fresco de Santiago en Clavijo de Pellegrino Tibaldi en la iglesia roamana del Sacro Cuore (antigua iglesia de San Giacomo degli Spagnoli) una de las posibles influencias de Alesio, ya que hay paralelismos entre ambos artistas como las telas, que en Pellegrino tienen un protagonismo muy peculiar y que indican una posible influencia en Alesio. Este fresco es un ejemplo de esa devoción específicamente española en Italia, la cual conocería el pintor por sus contactos con los círculos españoles. Un culto que llega en 1492 con Inocencio VIII, de la mano de los españoles, cuando se funda el hospital y la iglesia de San Giacomo degli Spagnoli en Roma. Más tarde sería usado por Felipe II como sede documental en relación con la corona, además de punto de referencia para los españoles residentes ${ }^{72}$, donde es muy posible que se moviera Alesio. Ya en 1502 se denomina a las pinturas de Santiago como "ad modum Yspanie" 73 . Pero sería uno de los alumnos de Rafael, Pellegrino da Modena (c. 1460-1523) el que en 1517 representa en Roma un Santiago en la Batalla de Clavijo ${ }^{74}$. Es interesante señalar el detalle del bocado del caballo ${ }^{75}$, representado con una mujer que lleva en la mano una brida en forma de $\mathrm{S}$ como la representada en el cuadro de Alesio. Una brida muy parecida la encontramos también en el San Jorge y el Dragón que

${ }^{71}$ LIEDTKE, Walter A.: The Royal Horse... op. cit., p. 42.

${ }^{72}$ ESPADAS BURGOS, Manuel y GARCIA ALÍA, Juan Carlos: Buscando a España en Roma, Madrid, CSIC-Dpto. de Publicaciones, 2006, p. 98.

${ }^{73}$ VÁZQUEZ SANTOS, Rosa: "Primeras conclusiones sobre el culto y la iconografía de Santiago el mayor en la ciudad de Roma", Archivo Español de Arte, LXXXIII, 2010, n³29, p. 19.

${ }^{74}$ Cuando en 1586 el ejército imperial reconquistó la ciudad de Colonia, el papa Sixto V "andó processionalmente da Monte Cavallo con 20 Cardinali alla Chiesa di San Jacomo de spagnoli...”, DANDELET, T. J.: La Roma española. 1500-1700, Barcelona, Cátedra, 2002, pp. 33, 50 y 113). VÁZQUEZ SANTOS, Rosa. "Primeras... op. cit., p. 19.

${ }_{75}$ TERVARENT, Guy de: Atributos y símbolos en el arte profano diccionario de un lenguaje perdido, Barcelona, Serbal, 2002; RIPA, Cesare: Iconologie, París, Ghent University Library, 1644, pp. 184 y187. 
realiza Rafael en 1505 (National Gallery, Washington), en el que vemos el detalle del bocado del caballo en forma de S muy similar al de Sevilla, pero además podemos apreciar cierta similitud en la mirada de ambos équidos.

El Mar. El Santiago en la batalla de Clavijo, obra de Paolo de San Leocadio, fechado entre 1513 y 1518, guarda un parecido asombroso en su composición con el de Alesio, aunque su estilo sea muy diferente. La disposición de los personajes, como el soldado de la parte inferior izquierda, que en la obra del lecese hemos definido como un san Miguel, aparece entrando en escena con parte del cuerpo cortado y con el mismo color de la coraza, la disposición de algunas armas que yacen en el suelo y un turbante. También coincide el paisaje de playa que se divisa al fondo. Las fechas coinciden más o menos con la obra de Pellegrino y algún modelo en común debían tener los tres artistas, posiblemente una imagen grabada. Si bien es cierto que en la leyenda de Santiago no existe el elemento acuático, en la de San Jorge y el dragón sí. Clavijo era una zona que no es cercana al camino ni al ámbito santiguista, por esto diversos autores han relacionado este tema con el de San Jorge y el dragón propio de esas tierras, identificando la misma lucha entre el bien y el mal, simbolizado por el dragón y los turcos, o la lucha contra el protestantismo ${ }^{76}$.

El estilo tardío de San Leocadio, de formación ferrarana, cercana al círculo de Mantegna, se advierte en la composición fragmentada en planos sucesivos y escalonados hasta la visión de un horizonte con una playa, asemejándose así en la obra de Alesio.

La playa del fondo de la obra de Alesio parece un mar cercano a una serranía. Sabemos que los montes de Clavijo están en tierra de Logroño, lejos de cualquier playa, hecho que conocían perfectamente Alesio y su mecenas. Según Cabrillana es una interpretación de la playa mediterránea que defendió Argote ${ }^{77}$ y quizá fuera allí donde se refiere cuando habla de su 'insigne victoria contra los moros' en las playas entre Fuengirola y Gibraltar, donde los moriscos derrotados bajaban para ir a Berbería y donde los esperaban los arcabuceros de las galeras reales. Pero otra interpretación, muy válida y muy poco conocida de Santiago, es su faceta de protector de los navegantes. Así lo evidencia su representación en el retablo de la Virgen del Buen Aire de Alejo Fernández, (Reales Alcázares de Sevilla, 1535), que se derivaba de la publicación del libro de los milagros del apóstol por Calixto II, donde se narra cómo el santo defiende en el año 1101 una nave repleta de peregrinos del ataque de un corsario moro y los guía hasta el puerto gallego, y cómo en el 1102 salva a un obispo de un naufragio. ${ }^{78}$

${ }^{76}$ CALVO DOMÍNGUEZ, Marcelina: Santiago el Mayor y la Leyenda Dorada, Santiago de Compostela, Museo de Bellas Artes da Coruña, Consellería de Cultura, Comunicación Social e Turismo, 1999, p. 186.

${ }^{77}$ CABRILLANA CIEZAR, Nicolás, Santiago Matamoros..., op. cit., p. 152.

${ }^{78}$ Ibidem., p. 154. 
La gamba. El profesor don Francisco Arquillo ${ }^{79}$ nos comentó que no pudo completar la restauración de la pintura de Santiago en Clavijo ya que la Hermandad le requirió la obra, habiéndose limitado únicamente a la sustitución del bastidor carcomido y a la retirada de un repinte en la zona inferior de unos treinta centímetros $^{80}$. Este añadido que se encontraba plegado por la parte trasera, era un fragmento, como indicaba López Martínez, "que denotaba una pésima calidad y donde abundaban moros que yacían muertos junto a armamento militar"

El resto de la documentación al respecto se encuentra traspapelada en los archivos de la Facultad de Bellas Artes de Sevilla. El profesor nos facilitó un informe mecanografiado de $1988^{82}$, que detalla el estado de conservación de la obra, aportando cuatro fotos donde se observa claramente la precariedad, tanto de la obra como de la iglesia: las humedades corrían por las paredes, la ubicación de la obra era provisional y se encontraba tapando parte del vano de acceso de la portería, provocando que quedara en voladizo casi medio metro de la esquina inferior izquierda. Hoy en día el cuadro se encuentra en unas condiciones bastante aceptables pero se mantiene fuera del retablo para el que fue creado, si bien es cierto que el retablo y parte de la iglesia requieren una restauración urgente ${ }^{83}$.

A este respecto es López Martínez quien ofrece noticias a cerca de las anteriores restauraciones en su ensayo de 1917 ${ }^{84}$ : la primera documentada fue en 1631 por Luis Ceballos y una segunda en 1716 por Juan Ruiz Soriano, sobre la que el historiador afirma que desvirtúa el original, recomendando una restauración. Detalla las medidas: 4,49 × 2,54 m, aclarando que a simple vista se ve claramente el añadido desde su parte inferior de 1,06 metros y añade que aunque en ese trozo

${ }^{79}$ Nuestro agradecimiento al profesor Jorge Ramón Corzo por su guía y su ayuda en las gestiones.

${ }^{80}$ Otros testigos presenciales, personas de la hermandad como Ángeles, la guardesa, y profesores de la Universidad de Sevilla, como Enrique Valdivieso, afirman que la parte retirada fue casi de un metro.

${ }^{81}$ LÓPEZ MARTÍNEZ, Celestino: Capítulos para la biografía..., op.cit., p.160

${ }^{82}$ CARRANZA PÉREZ, Celia María: Informe realizado cuando fue alumna de tercer curso, fechado el 19 de mayo de 1988, con documentación fotográfica del estado del cuadro, cuadernillo e hojas taquigrafiadas con fotografías en blanco y negro en los últimos folios.

${ }^{83}$ Nuestro agradecimiento a Ángeles por su ayuda y disposición en las largas sesiones de fotografía.

${ }^{84}$ LÓPEZ MARTÍNEZ, Celestino: Capitulos para la biografía del historiador Argote de Molina, Madrid, Asociación española para el progreso de la ciencia, 1917, tomo VIII, sección 6, pp. 160-161; "Doscientos y setenta reales pagados a Juan Soriano, maestro pintor, por componer el cuadro de la imagen de Señor Santiago del altar mayor de esta iglesia, assi de Lienzo nuevo que le echó, como de tachuelas, pintura y embarnizado; consta de recibo del susodicho con fecha en 17 de octubre de 1726, que se rubricó y abonan." Archivo Parroquial de Santiago, Libro de cuentas de 1725 a 1728. 
se repiten las figuras y objetos de la parte antigua, denota una inferior calidad técnica. También dice González de León que 'este cuadro esta añadido por la parte de abajo y desdice mucho de la obra'.

El informe de 1988, anteriormente citado, único al que hemos tenido acceso por ahora, difiere del anterior porque nos ofrece otras medidas: 4,73 x 3,43 cm, al tiempo que fecha la restauración del profesor Arquillo en 1985. Otra posible restauración es la propuesta por Enrique Valdivieso, según el cual habría sido realizada por Pedro Tortolero hacia 1789.

Por nuestra parte, tomamos las medidas con un medidor láser bastante preciso ${ }^{85}$ y el resultado fue: $3,553 \mathrm{~m}$ de alto y $2,963 \mathrm{~m}$ de ancho. También tomamos medidas del espacio del retablo: 4,737 $\mathrm{m}$ de altura por 2,911 $\mathrm{m}$ de ancho, por lo que nos quedaría un espacio sobrante de 1,2 metros, que se corresponde exactamente con la parte de la obra retirada, que ya indicaba López Martínez.

La hipótesis que sostenemos es que el añadido no es, como dice el historiador 'copia del original', sino más bien una ampliación por haberse arruinado posiblemente la parte superior y como él mismo dice, de esta parte inferior no contiene nada esencial del asunto del mismo, como sí poseería la parte superior. El restaurador seguramente prefirió llenar el campo de batalla a los pies del caballo que el rompimiento de gloria que nosotros proponemos, el cual debió encontrarse pintado en la parte superior. Para mantener esta hipótesis nos basamos en la figura de dos pies (fig.10) que aparecen cortados en la parte superior del cuadro y de los que, hasta la fecha, nadie ha hecho mención. Dichos pies aparecen desde las fotos más antiguas de 1972, aunque casi imperceptibles, posteriormente en las de 1980 con más nitidez y en las que realizamos en 2012 -con la ayuda de varios colaboradores $^{86}$ y un teleobjetivo ${ }^{87}$-, donde se aprecian muy claramente.

A este detalle lo hemos denominado la gamba, en relación a la tan famosa como apócrifa anécdota del comentario de Alesio sobre la pierna del Adán en $L a$ Genealogía de Cristo de Luis de Vargas (1561) de la capilla cercana al fresco de San Cristóbal en la catedral hispalense. Alesio exclamó: "Piú vale la tua gamba che tutto il mio S. Cristoforo", según la leyenda recogida por Palomino en $1715^{88}$ y seguida por muchos otros con posterioridad ${ }^{89}$; y a partir de mediados del siglo XX

${ }^{85}$ Medidor láser marca Leica Disto Classic 5 a.

${ }^{86}$ Para esta labor he contado con la ayuda de los fotógrafos Jorge Cerquera y Daniel Puertas Márquez.

${ }^{87}$ Objetivo Sigma DG 70-300mm 1:4-5-6 para cámara Canon EOS 400D.

${ }^{88}$ PALOMINO DE CASTRO Y VELASCO, Antonio: El Museo pictórico y escala óptica. Madrid, 1715-24, t.I., pp. 266-267.

${ }^{89}$ PRECIADO DE LA VEGA, Francisco: Carta a Giovanni batista Ponfredi sobre la pintura Española, Madrid, 1765; PONZ, Antonio: Viage de España, en que se da noticia de las cosas más apreciables y dignas de saber, que hay en ella. t. 9, Madrid, Ibarra, Joaquín, 1780, pp. 24-25; ORTIZ DE ZUÑIGA, Diego: Anales eclesiástico y seculares de la muy 
rebatida por los Mesa y Gisbert y Bernales ${ }^{90}$, sobre la base inapelable de que Luis de Vargas murió en 1567 y el fresco lo pinta Alesio en 1594.

El famoso comentario sobre la obra de Vargas, aunque elogia el detalle, superponiendo el lienzo de Vargas a su propio fresco y homenajeando así al verdadero introductor de la técnica, no puede ser interpretado como un arranque de modestia hacia un autor que reconocía, puesto que se había formado en Italia en los círculos rafaelescos, sino que parece ser un reflejo de otra anécdota documentada, la de su amigo Jacopo Palma, el cual ya viejo en el año 1625, le comenta al embajador de Urbino frente al cuadro de San Pedro Mártir de Tiziano, vale más este cuadro, que todo el convento con los frailes dentro ${ }^{91}$. Tal cita ha sido deformada con el tiempo hasta generar la anécdota de la gamba. Tampoco nos hace pensar que ese fragmento retirado a la obra tuviera que ser realmente copia del original, como menciona López Martínez, sino más bien justifica nuestra hipótesis de que ese metro veinte que le falta pudiera ser de la parte superior donde el pie indica que hubo algo. ¿Acaso un rompimiento de gloria? ¿Una trinidad sentada? Tendría que ser algo que justificase una gran mancha oscura sobre la que estarían las figuras, unas nubes seguramente.

En este punto es significativo recurrir a alguna de las poquísimas obras documentadas que nos quedan del artista, como el dibujo conservado en la Colección Alcubierre, seguramente de la época sevillana, como indican Mesa y Gisbert ${ }^{92}$. Este nos proporciona una posible similitud con esas figuras que debieron aparecer en la parte superior componiendo una gloria, la cual estaría formada posiblemente por un Dios Padre e Hijo sentados juntos, dada la diferencia entre ambos pies.

$\mathrm{Si}$ atendemos al espacio restante, de 1,2 metros, estaríamos ante figuras sedentes, y no en pie. Alguna pista, por las similitudes entre ambas obras nos la podría proporcionar Roelas en su cuadro La Gloria, actualmente en el museo de

noble y muy leal ciudad de Sevilla (de 1246 a 1671), Madrid, Imprenta Real, 1796, t. III, pp. 226; SANCHEZ CANTÓN, Francisco Javier: Fuentes Literarias para la Historia del Arte Español. Madrid, Imprenta Clásica Española, 1933, p. 453.

${ }^{90}$ MESA, José de y GISBERT, Teresa: El pintor Mateo Pérez de Alesio, La Paz, Cuadernos de Arte y Arqueología, Institutos de Estudios Bolivianos, Universidad Mayor de San Andrés, 1972, pp. 57; BERNALES BALLESTEROS, Jorge: "Mateo Pérez De Alesio, Pintor Romano En Sevilla y Lima". Archivo Hispalense: Revista Histórica, Literaria y Artística, 1973, vol. 56, n. 171, p. 228.

${ }^{91}$ Alessandro Diplovatazio, embajador de Urbino en Venecia en el 1628, a pocos meses de la muerte de Jacopo, le escribe al duque Francesco María su señor, contándole haber encontrado al viejo pintor contemplando el martirio del san Pedro de Tiziano en la iglesia dominica de los Santos Giovanni y Paolo. IVANOF, Nicola, ZAMPETTI, Pietro. Palma il giovane, Bergamo, Banca Popolare, 1975. p. 429; PALESATI, Antonio y LEPRI, Nicoletta, op. cit., p. 156.

${ }_{92}$ MESA, José de y GISBERT, Teresa; El pintor Mateo Pérez de..., op. cit., p. 68. 
la Catedra $^{93}$, en el cual podemos apreciar un esquema compositivo que, seguramente por analogía entre lo descrito y por esa mancha oscura, estaría cerca.

La falta de documentos, tanto escritos como visuales sobre la obra nos obligan a elucubrar como sería esa composición. Si bien encontramos un grabado previo considerado como antecesor a la llegada de Alesio a Sevilla, La Conversión de San Pablo ${ }^{94}$ (fig.10), producida en 1583 y que nos resulta muy interesante por su dedicatoria a Enrico Guzmán ${ }^{95}$, conde de Olivares, el embajador español que llegó a Roma en junio del año anterior. La inscripción, datada en 1583, dice claramente que fue diseñado y publicado por Pérez y grabado por Perret. En esta obra observamos como Cristo, desde un rompimiento de gloria, envía una rayo de luz a san Pablo, que se encuentra en el suelo; y al igual que en la obra de Santiago en Clavijo, el santo mira extasiado hacia arriba, de donde le llega un fino rayo de luz que parte desde los pies cortados a los ojos. En obras anteriores de Alesio, también encontramos escenas que nos darían la pista de cómo podría ser dicha escena cortada, como en el Bautismo de Cristo de la catedral maltesa de La Valetta, donde Alesio coloca también un rompimiento de gloria con un dios Padre.

Hemos revisado anteriores representaciones de Santiago, hallando solo una con un rompimiento de gloria que podría ser similar: la pintura realizada de Rodríguez Losada en la Iglesia de Santiago de Jerez de la Frontera en 1890, en el cual observamos muchas concomitancias con respecto la obra de Mateo Pérez de Alesio. Losada fue pintor de temas de historia, formado en Sevilla y caballero de la orden de Santiago ${ }^{96}$, lo que nos hace pensar que pudo haber tenido acceso a la obra completa de Alesio o a alguna otra información sobre ella, grabados o descripciones, sobre todo durante su período formativo y posteriormente la documentase para su obra jerezana. Las coincidencias con la de Alesio avalarían nuestra la hipótesis.

Fecha de recepción: 30 de septiembre de 2014

Fecha de aceptación: 28 de noviembre de 2014

${ }^{93}$ VALDIVIESO, Enrique: Historia de la pintura española: escuela sevillana del primer tercio del siglo XVII, Sevilla CSIC, 1985, p. 122.

${ }^{94}$ Uno de ellos se conserva en el Gabinete de estampas y grabados del Museo de los Uffici, y hemos localizado otra copia en el British Museum.

95 "ILLmo. ET EXCmo. Dno. HENRIQVIO GVZMANO COMITI OLIVARIENSI LEGATO REGIS HISPANIARVM PHILIPPII APVD GREGORN[M]/PONT. MAX. VIRO RELIGIONE PROBITATE GENERIS SPLENDORE CONSILIO ET PRVDENTIA INCOMPARABILI MATTHAEVS/PEREZIVS LECCIENSIS AFFECTVS ET OBSERVANTIAE CAVSA DEDICABAT. ROMAE ANNO D[OMI]NI M.D.L.XXXIII".

${ }^{96}$ PÉREZ CALERO, Gerardo: El pintor José María Rodríguez Losada (1826-1896) y la orden de Caballería del Santo Ssepulcro, Zaragoza, Fundación Salvador Ibarra Franco, 2004, pp. 416-130. 


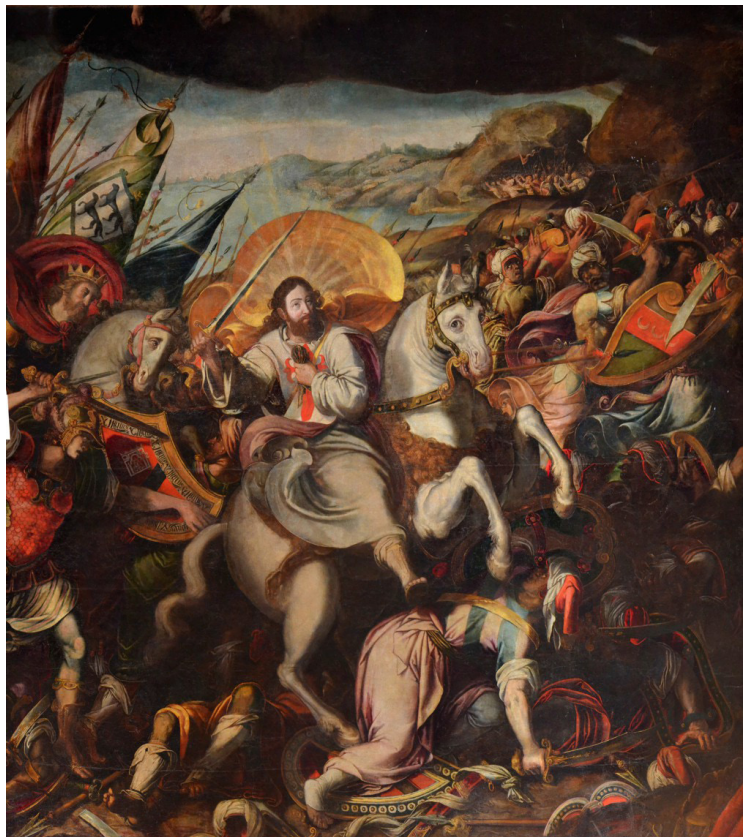

Figura 1. "Santiago en la Batalla de Clavijo". Mateo Pérez de Alesio. 1586. Iglesia de Santiago el viejo, Sevilla.

Fotografía: Daniel Puertas Márquez. 2012.

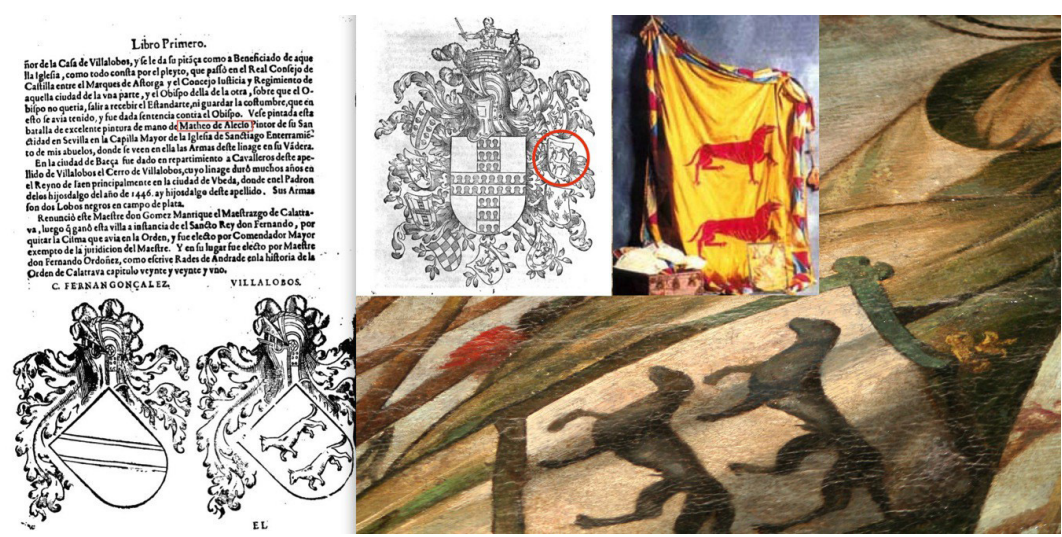

Figura 2. De izquierda a derecha: la pagina de la Nobleza de Andalucía, con la referencia a Alesio y el escudo de villalobos, el emblema de Argote de Molina, con resalte en circulo del detalle.

La seña, actualmente en la Catedral de Astorga, y el detalle del cuadro de la batalla de Clavijo. 


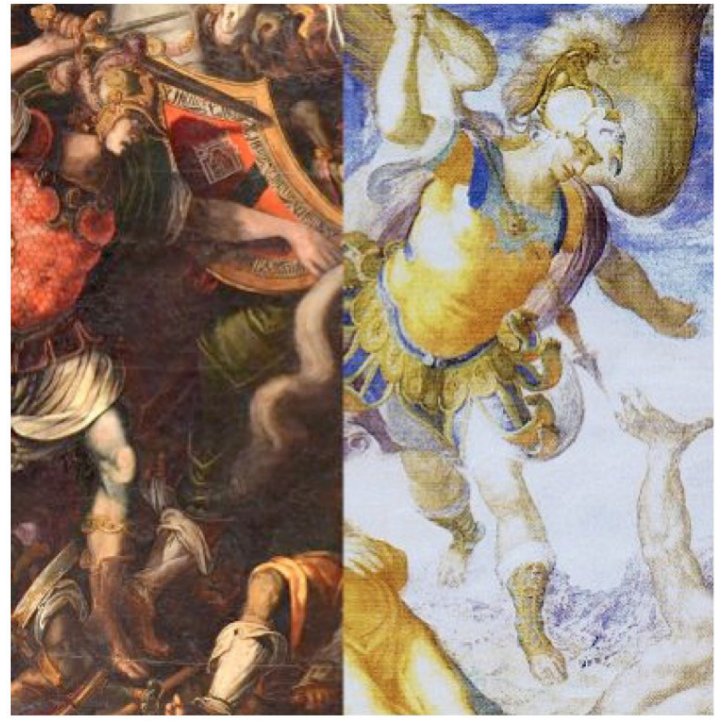

Figura 3. Detalle del soldado de la batalla de Clavijo y detalle del San Miguel, del fresco de la Capilla Sixtina, ambas obras de Mateo Peréz de Alesio.

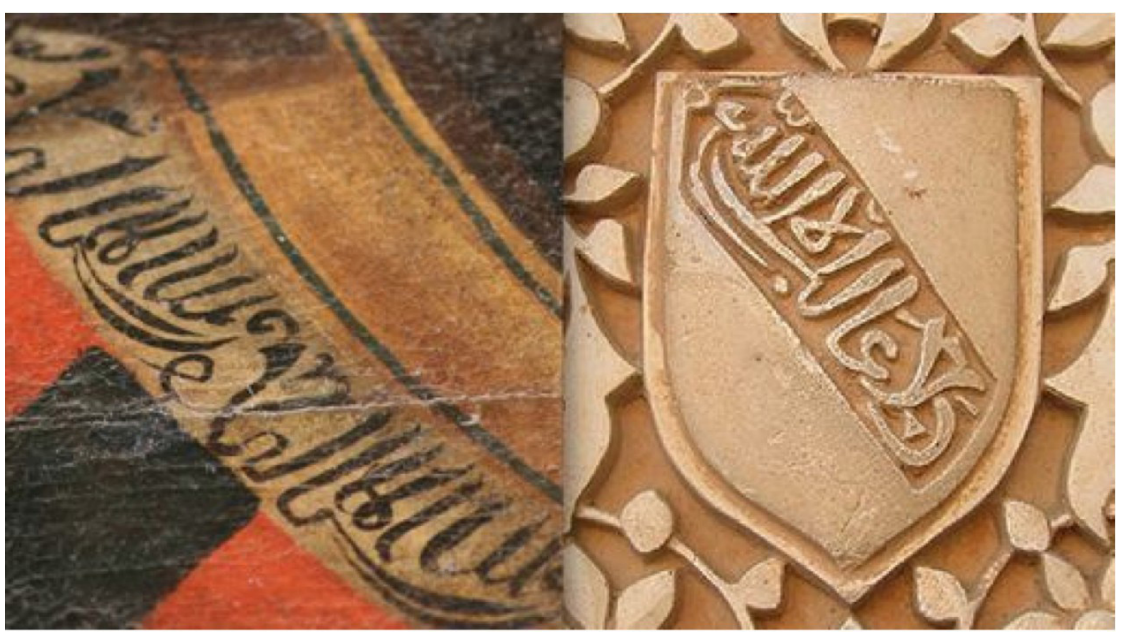

Figura 4. Detalle del escudo donde se aprecia la inscripción, en "la batalla de Clavijo" (foto. Ignacio Algarín) y detalle de las yeserías de la Alhambra donde se aprecia el escudo de la banda. 


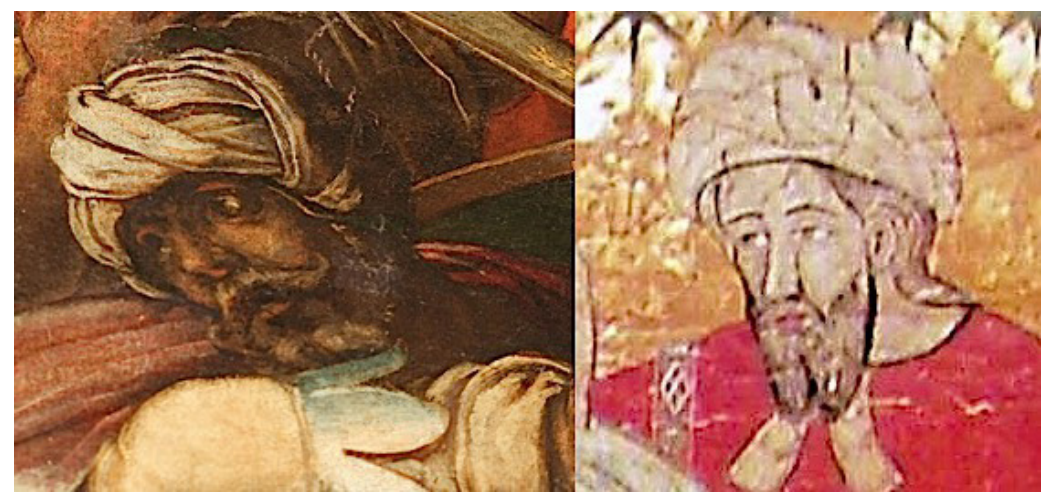

Figura 5. Detalle del Emir, De "la batalla de Clavijo", foto. Ignacio Algarín. Detalle de un rey Alhamar, en la bóveda de la "sala de la justicia", de la Alhambra.

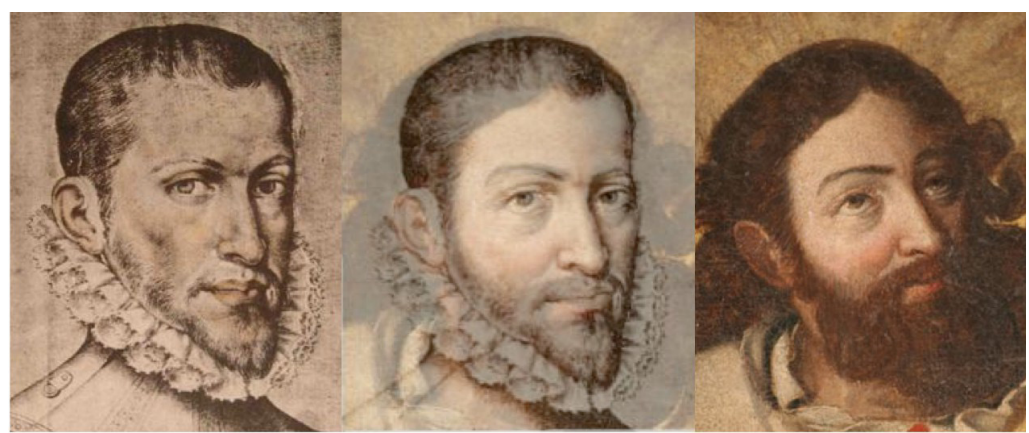

Figura 6. Secuencia del montaje del retrato de Argote de Molina, por Pacheco y el Rostro de Santiago por Alesio.

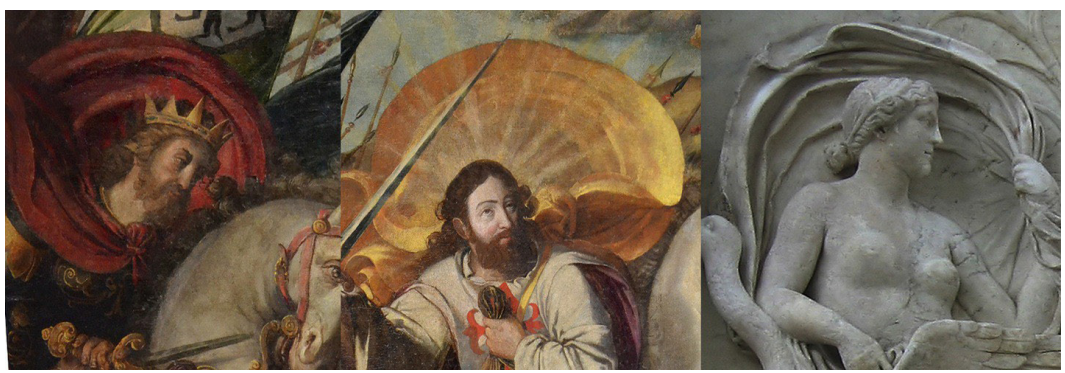

Figura 7. Detalle de San Fernando y de Santiago, resaltados con la capa, fotografía: Ignacio Algarín. Detalle del Ara Pacis, con el mismo motivo. 


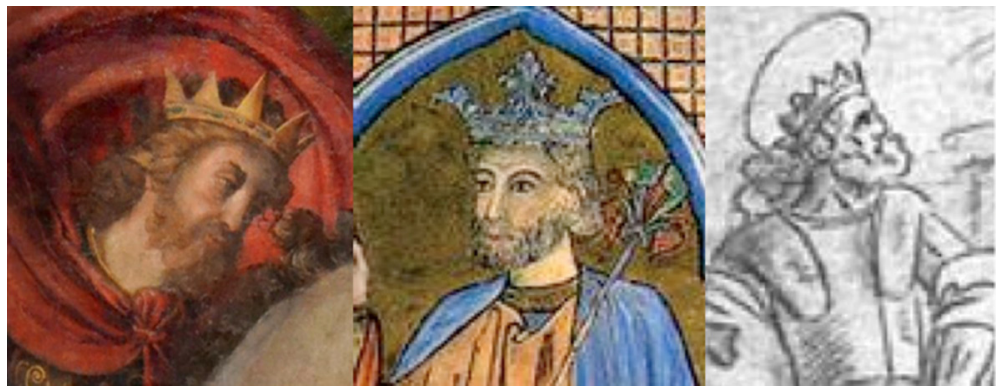

Figura 8. Ramiro I como San Fernando, detalle de Pérez de Alesio, foto: Ignacio Algarín González 2012; Fernando III en el Tumbo A,

Catedral de Santiago s.XIII; Fernando no admite los vasos sagrados en el sitio a Sevilla, dibujo de Fernando del Castillo de 1534, Gabinete de Dibujos.

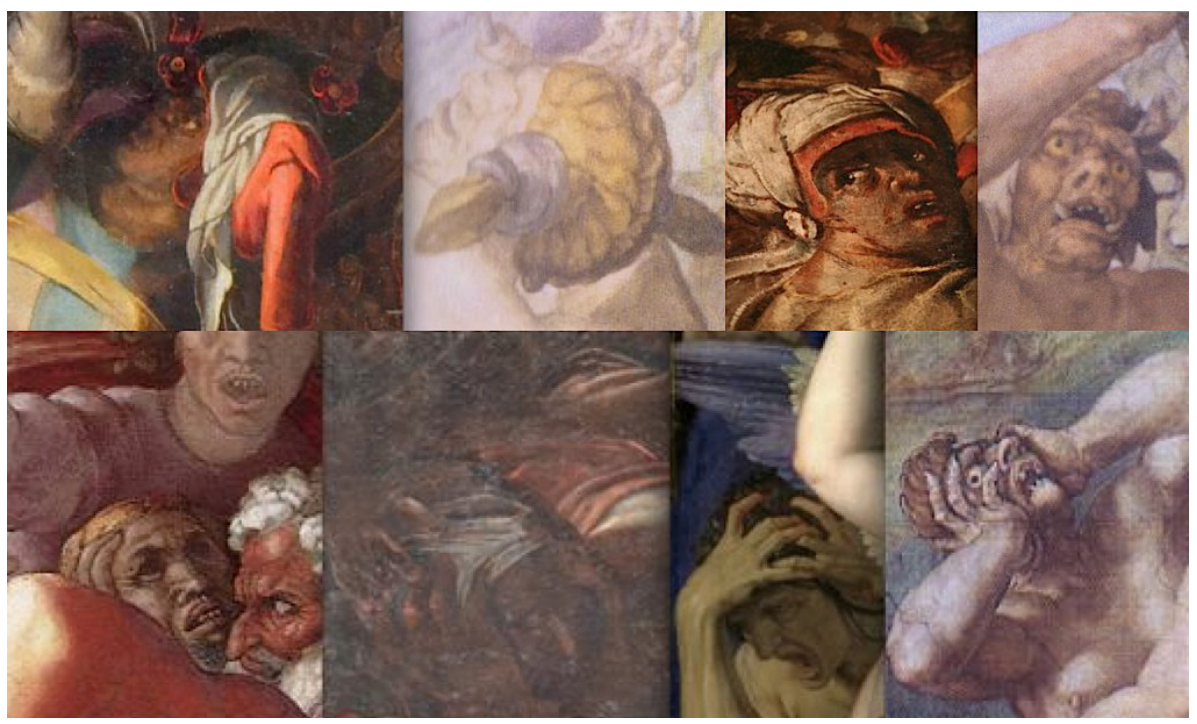

Figura 9. Línea superior -detalles de posiciones grotescas con las manos. De izq. Detalle de la Capilla Sixtina, escena del fresco de Noe区, segundo: detalle de la batalla de Clavijo, tercero: detalle de la alegoría de los celos en la "el triunfo de Venus" de Bronzino, 1540, por ultimo un detalle de demonio de Alesio en el fresco de la capilla sixtina.

Línea inferior - dos detalles de musulmanes de la batalla de Clavijo y sus correspondientes en la Capilla Sixtina, ambos obras de Mateo Pérez de Alesio. 

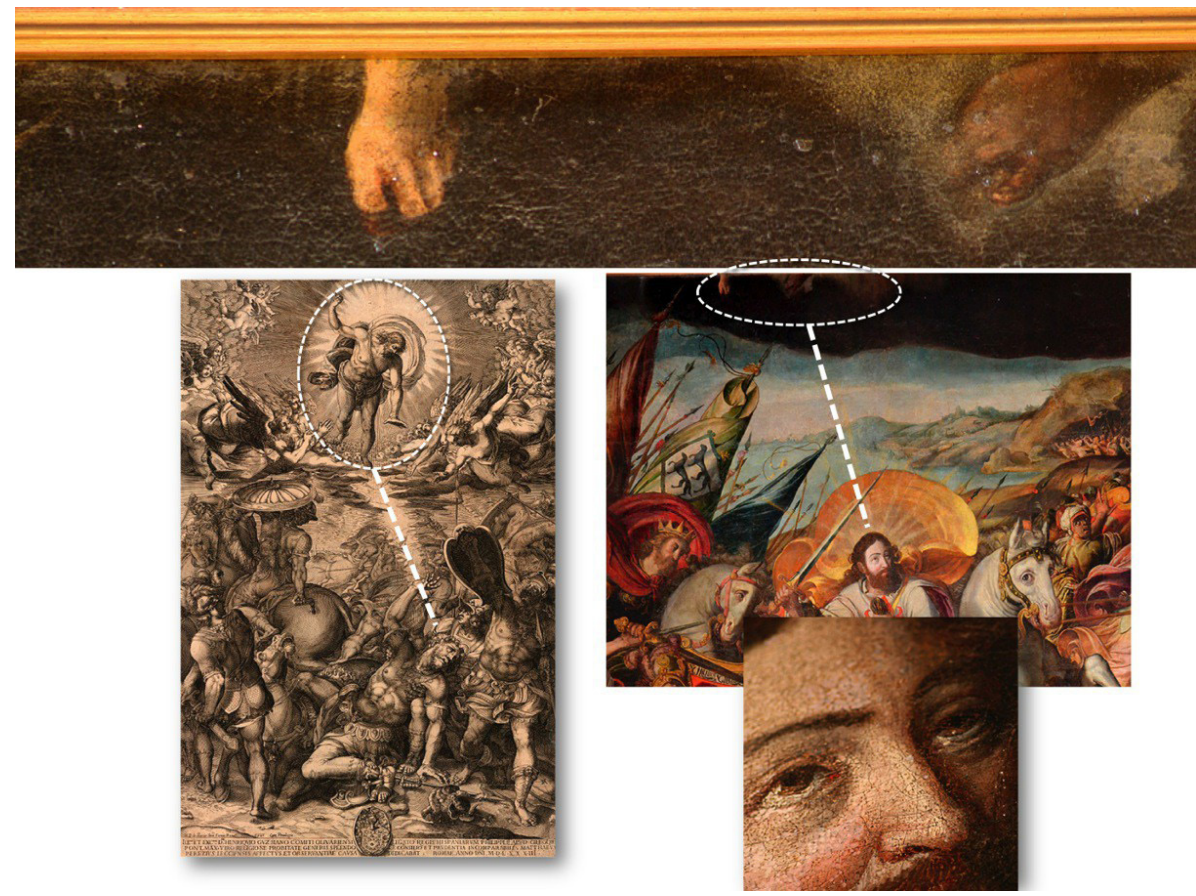

Figura 10. Montaje de la hipótesis defendida, "la gamba", en la parte superior el detalle de los dos pies, abajo izq. explicación de la composición sobre el grabado de "la conversión de San Pablo" Aguafuerte de Mateo Pérez de Alesio, Roma, 1583, 1 British Museum. 